\title{
Surviving Drosophila eye development
}

\author{
Nancy M. Bonini \\ Department of Biology, University of Pennsylvania, Philadelphia, PA 19104- \\ 6018, USA; tel: 215-573-9267; fax: 215-898-8780 e mail: \\ nbonini@sas.upenn.edu
}

Received 17.6.96; revised 30.8.96; accepted 6.9.96

Edited by $\mathrm{H}$. Steller

\begin{abstract}
During eye development, cell death interplays dynamically with events of differentiation to achieve the remarkably patterned structure of the fly compound eye. Mutations in genes that affect the normal developmental process can lead to excessive death of progenitor cells, or, alternatively, to the differentiation of supernumerary neurons, pigment and cone cells due to survival of cells that would normally be eliminated. These data reveal that eye development contains cell selection processes: only certain cells are selected to undergo differentiation, and supernumerary cells are actively eliminated by cell death pathways to achieve the highly ordered lattice of the eye. The final number of cells that comprise the eye is controlled through a balance of cell proliferation with proper cell differentiation and removal by cell death.
\end{abstract}

Keywords: cell death, cell differentiation, cell selection, apoptosis, Drosophila, compound eye

Abbreviations: $d p p$, decapentaplegic; EGF, epidermal growth factor; emc, extra macrochaetae; hid, head involution defective

\section{Introduction}

The Drosophila eye provides a system approachable with genetic and molecular tools for understanding signal transduction pathways and cell-cell interactions involved in differentiation. During the developmental process, cell survival interplays crucially with cell differentiation to generate the highly precise array of photoreceptor neurons and accessory cells of the eye. The adult compound eye comprises approximately 800 individual ommatidia, each consisting of an ordered array of eight photoreceptor neurons with a complement of accessory cells including four cone cells, two primary pigment cells, shared secondary and tertiary pigment cells and bristle cell (reviewed in Wolff and Ready, 1993) Differentiation commences in the mid-third larval instar with a wave of development marked by the morphogenetic furrow, which progresses from posterior to anterior across the epithelial field of progenitor cells (Ready et al, 1976). Anterior to the furrow, progenitor cells are dividing; posterior to the furrow clusters of cells destined to become the adult ommatidial units undergo cell-cell interactions and cell selection events of differentiation.
Although much attention has focused on targetdependent survival (reviewed by Cowan et al, 1984; Oppenheim, 1991; Raff et al, 1993), a cell's developmental history is comprised of multiple stages when survival is critical. In the fly eye, cell death functions at several times to sculpt the selection of cells (Figure 1): one selection process occurs prior to the major differentiation hurtle of the furrow; a second occurs posterior to the furrow during cellular interactions involved in differentiation of the clusters (Wolff and Ready, 1991; Bonini et al, 1993; Hay et al, 1994); and a third in final stages of pattern formation to eliminate supernumerary cells associated with each cluster and establish the highly ordered lattice of the adult eye (Cagan and Ready, 1989a). Exquisite coordination of events of differentiation, including cell cycle regulation, is required for appropriate cell development; loss of coordination can lead to loss of cells by death. Here, we focus on the integration of cell survival strategies with the cell differentiation process at various stages of eye development, emphasizing genes whose altered function leads to changes in cell death patterns of cells in the eye (Table 1). Given the many striking examples of conservation of gene sequence and function between Drosophila and humans (e.g. Halder et al, 1995; Banfi et al, 1996), these studies have application to vertebrate development mechanisms (see accompanying reviews). Recent reviews emphasizing other aspects of Drosophila eye development include Thomas and Zipursky (1994), Zipursky and Rubin (1994), Bonini and Choi (1995), Heberlein and Moses (1995). Recent coverage of genes of Drosophila cell death pathways is found in White and Steller (1995).

\section{Interweaving cell survival with pattern formation}

\section{Prior to the furrow}

Key genes that function anterior to the furrow in eye development include eyeless, sine oculis and eyes absent. The eyeless gene encodes a Pax- 6 homeobox homolog (Quiring et al, 1994), sine oculis a homeobox gene (Cheyette et al, 1994; Serikaku and O'Tousa, 1994), and eyes absent a novel nuclear protein (Bonini et al, 1993). Ectopic expression of eyeless in other tissues can induce the formation of eyes; eyeless is thus thought to be a fundamental control gene for eye formation and is highly conserved from flies to mammals (Halder et al, 1995; see Zuker, 1994). Given this role of eyeless, the sine oculis and eyes absent genes may function in concert with or as targets of eyeless activity, both genes being essential for eye formation with their loss of function leading to loss of the adult compound eye. They may function in a number of biological events, including to determine which cells are competent to form eye, cell survival and initiation of pattern formation with the furrow (below). 


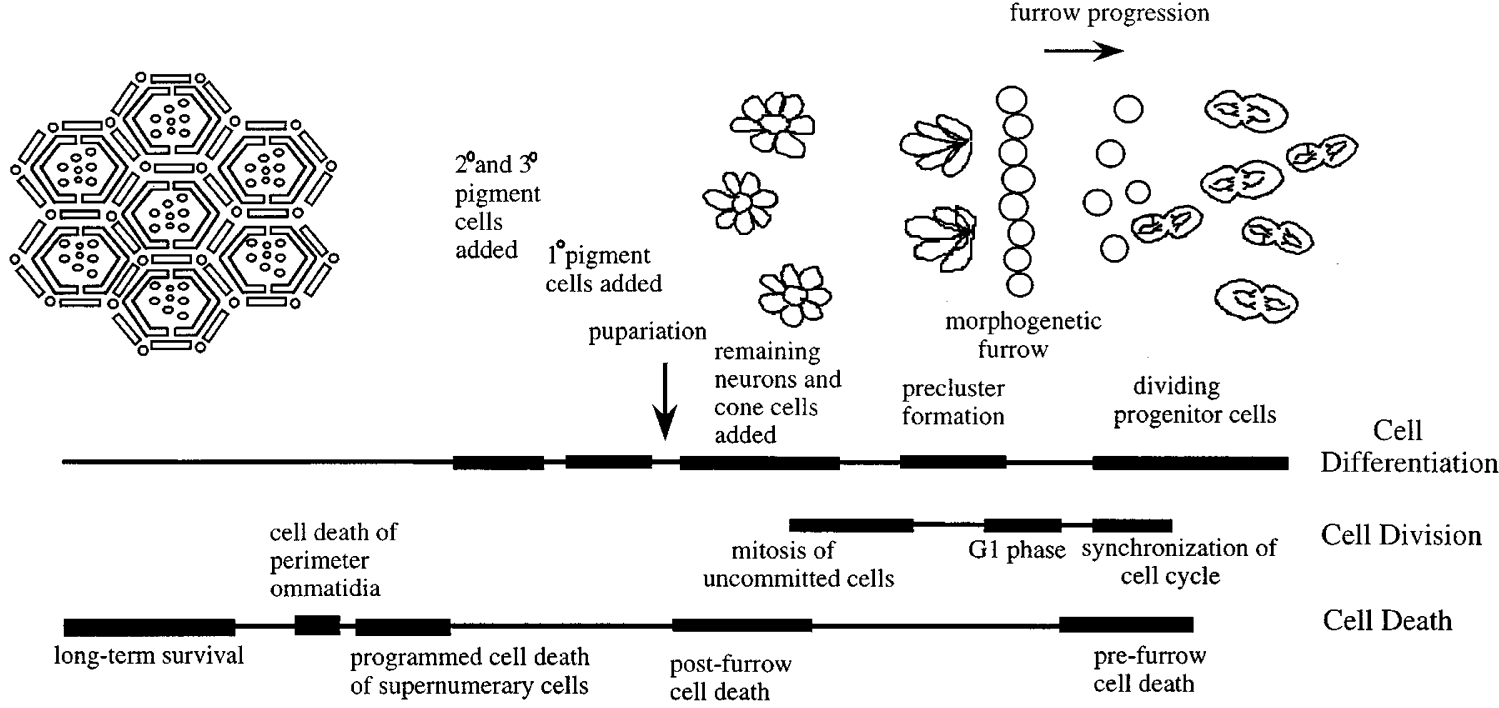

Figure 1 Drosophila eye development from the third instar larval stage (right) to the neurocrystalline lattice of the adult eye (left), with The approximate relative timing of events of cell differentiation, cell division, and cell death. Anterior to the furrow, cells are dividing (Ready et al, 1976). Close to the furrow, cell cycle synchronization occurs (Thomas et al, 1994), and a phase a cell death takes place (Wolff and Ready, 1991; Bonini et al, 1993; Hay et al, 1994). In the furrow, cells are in the G1 phase of the cell cycle (Thomas et al, 1994). Posterior to the furrow, the first events of cell differentiation are seen with preclusters of photoreceptor neurons forming (reviewed in Wolff and Ready, 1993). Subsequently, a final round of mitosis takes place (Ready et al, 1976) and additional cells are added to the clusters, including the remaining photoreceptor neurons and the cone cells. In the more posterior region of the disc beginning around 12 rows behind the furrow, another phase of cell death occurs (Wolff and Ready, 1993). During the pupal period, the primary, secondary and tertiary pigment cells are added, followed by a phase of cell death which removes supernumerary cells to sculpt the final pattern of the neurocystalline lattice (Cagan and Ready, 1989a; Wolff and Ready, 1991). This phase is followed by the death of cells of perimeter ommatidia (Wolff and Ready, 1991). Mitosis and development of the bristle cells occurs during the pupal period, and is not indicated here (see Wolff and Ready, 1993). In the adult, the compound eye is maintained by trophic interactions, due to connections between the photoreceptor neurons and the brain (Campos et al, 1995).

Loss-of-function mutations of the eyeless, eyes absent or sine oculis genes increases the amount of cell death that occurs anterior to the furrow (Fristrom, 1969; Bonini et al, 1993; Cheyette et al, 1994; Serikaku and O'Tousa, 1994). This cell death, as with most other cell death referred to here, has morphological and histological features characteristic of programmed cell death (Kerr et al, 1972; Wolff and Ready, 1991; Abrams et al, 1993), although which programmed cell death genes are activated in these mutants has not yet been addressed. The timing of excessive cell death in these mutants overlaps the period of normal death of some cells ahead of the furrow (Spreij, 1971; Wolff and Ready, 1991; Bonini et al, 1993). This spatiotemporal overlap suggests that a cell selection event occurs just anterior to the furrow: for example, at this time, cells with the right set of factors and at the appropriate stage of the cell cycle will proceed into the differentiation process marked by the furrow, whereas others, developmentally or otherwise amiss or deemed extraneous, become eliminated by activation of programmed cell death.

Although the reason why cells are normally eliminated ahead of the furrow is unknown, the time in development provides a logical point in eye formation at which cell selection should occur. At this time, the preliminary number of cells that will comprise the adult eye is defined. The total cell number will reflect the number generated by division (ahead of the furrow and in one additional wave of mitosis posterior to the furrow), minus the number eliminated by cell death. Instead of controlling precise cell number by the number of cell divisions (cell lineage), the animal appears to have acquired a degree of plasticity in that progenitor cells continually divide and may compete for differentiation. The appropriate number of cells is selected in parallel with the progression of cell differentiation. Such developmental flexibility incorporates plasticity required to generate a structure of the appropriate size to match the size of the animal which may depend upon environmental conditions, nutritional state, and other criteria: for any one fly, the total number of ommatidia is distinct, although falls in a range of 745 to 828 for females, with an average of 776 (Ready et al, 1976). Analysis of mutants like eyeless, sine oculis and eyes absent indicates that proper function of these genes is one checkpoint for cell differentiation at the furrow.

Distinctions exist between sine oculis and eyes absent mutants in positional information of cells that survive, suggesting that the two genes are involved in at least partially distinct aspects of the differentiation process. In sine oculis mutants, islands of eye progenitor cells that survive in weak alleles (which generate partial eyes) maintain their dorsoventral positional information within the eye disc, such that their photoreceptor axons make the appropriate dorsoventrally positioned contacts in the brain (Kunes et al, 1993). In contrast, in weak eyes absent mutations, cells that develop are always located at the most posterior tip of the eye field (Bonini et al, 1993), and are therefore not anticipated to retain prior positional information. 
Table 1 Listing of some eye developmental genes that influence cell survival

\begin{tabular}{|c|c|c|c|}
\hline Gene & $\begin{array}{l}\text { Mutant } \\
\text { phenotype and } \\
\text { influence on cell survival }\end{array}$ & $\begin{array}{l}\text { Gene product } \\
\text { and function }\end{array}$ & References \\
\hline \multicolumn{4}{|l|}{ Early genes } \\
\hline eyeless & $\begin{array}{l}\text { Reduced eye/eyeless; cell death } \\
\text { ahead of the furrow }\end{array}$ & $\begin{array}{l}\text { Pax-6 homeodomain homolog; can } \\
\text { induce ectopic eye formation }\end{array}$ & $\begin{array}{l}\text { Fristom, 1969; Quiring et al, 1994; } \\
\text { Halder et al, } 1995\end{array}$ \\
\hline eyes absent & $\begin{array}{l}\text { Reduced eye/eyeless; cell death } \\
\text { ahead of the furrow }\end{array}$ & $\begin{array}{l}\text { Novel nuclear protein; functions } \\
\text { ahead of the furrow }\end{array}$ & Bonini et al, 1993 \\
\hline sine oculis & $\begin{array}{l}\text { Reduced eye/eyeless; cell death } \\
\text { ahead of the furrow }\end{array}$ & $\begin{array}{l}\text { Homeodomain protein; functions } \\
\text { ahead of the furrow }\end{array}$ & $\begin{array}{l}\text { Cheyette et al, 1994; Serikaku and } \\
\text { O'Tousa, } 1994\end{array}$ \\
\hline dachshund & $\begin{array}{l}\text { Reduced eye/eyeless; cell death and } \\
\text { transformation of eye tissue to cuticle }\end{array}$ & $\begin{array}{l}\text { Novel nuclear protein; role in furrow } \\
\text { initiation }\end{array}$ & Mardon et al, 1994 \\
\hline \multicolumn{4}{|l|}{ Furrow progression } \\
\hline$d p p$ & Reduced eye/eyeless; cell death & $\begin{array}{l}\text { TGF } \beta \text { homolog; functions non- } \\
\text { autonomously in furrow propagation }\end{array}$ & Bryant, 1988; Heberlein et al 1993b \\
\hline hedgehog & $\begin{array}{l}\text { Reduced eye; cell death ahead of the } \\
\text { furrow }\end{array}$ & $\begin{array}{l}\text { Functions in non-autonomous } \\
\text { signalling for propagation of the } \\
\text { furrow }\end{array}$ & Ma et al, 1993 \\
\hline \multicolumn{4}{|l|}{ Cell cycle control } \\
\hline roughex & $\begin{array}{l}\text { Failure of G1 arrest in the furrow; } \\
\text { extensive cell death after the furrow }\end{array}$ & $\begin{array}{l}\text { Novel protein; functions with string to } \\
\text { synchronize cells in the furrow in G1 }\end{array}$ & Thomas et al., 1994 \\
\hline string & G2 arrest & $\begin{array}{l}\text { Homolog of mitotic inducer cdc } 25 \text {; } \\
\text { functions with roughex to synchronize } \\
\text { cells in the furrow in G1 }\end{array}$ & $\begin{array}{l}\text { Alphey et al, 1992; Thomas et al, } \\
1994\end{array}$ \\
\hline \multicolumn{4}{|c|}{ Spacing of the clusters } \\
\hline atonal & Eyeless; cell death after the furrow & $\begin{array}{l}\text { Proneural gene; required for } \\
\text { establishing founder cell of each } \\
\text { ommatidial cluster }\end{array}$ & Jarman et al, 1994, 1995 \\
\hline Ellipse & $\begin{array}{l}\text { Reduced eye; influences mitosis and } \\
\text { differentiation of progenitor cells; } \\
\text { increases cell death after the furrow }\end{array}$ & $\begin{array}{l}\text { EGF receptor homolog; affects } \\
\text { precluster formation }\end{array}$ & Baker and Rubin, 1989, 1992 \\
\hline \multicolumn{4}{|c|}{ Pigment cell selection } \\
\hline $\begin{array}{l}\text { roughest (also } \\
\text { irregular chiasm C) }\end{array}$ & $\begin{array}{l}\text { Rough eye due to survival of } \\
\text { supernumerary pigment cells }\end{array}$ & $\begin{array}{l}\text { Transmembrane protein with } \\
\text { immunoglobulin-like domains }\end{array}$ & $\begin{array}{l}\text { Wolff and Ready, 1991; Ramos et al, } \\
\text { 1993; Schneider et al, } 1995\end{array}$ \\
\hline echinus & $\begin{array}{l}\text { Rough eye due to survival of } \\
\text { supernumerary cells }\end{array}$ & & Wolff and Ready, 1991 \\
\hline $\begin{array}{l}\text { argos (also giant lens } \\
\text { or strawberry) }\end{array}$ & $\begin{array}{l}\text { Extra photoreceptor, pigment and } \\
\text { bristle cells due to survival and } \\
\text { differentiation of supernumerary cells } \\
\text { in the larval eye disc and during } \\
\text { pupal stages }\end{array}$ & $\begin{array}{l}\text { Protein with EGF motif that functions } \\
\text { non-autonomously; inhibits } \\
\text { neighboring cells from adopting } \\
\text { identical fates }\end{array}$ & $\begin{array}{l}\text { Freeman et al, 1992; Kretzschmar et } \\
\text { al, 1992; Okano et al, 1992; } \\
\text { Brunner et al, 1994; Schneider et al, } \\
1995\end{array}$ \\
\hline \multicolumn{4}{|c|}{ Genes of programmed cell death pathways } \\
\hline reaper & $\begin{array}{l}\text { Within } 300 \mathrm{~kb} \text { deletion that is required } \\
\text { for programmed cell death in the } \\
\text { embryo }\end{array}$ & $\begin{array}{l}\text { Novel; expressed in cells that will } \\
\text { undergo cell death; ablates the eye } \\
\text { when ectopically expressed }\end{array}$ & $\begin{array}{l}\text { White et al, 1994, 1996; Hay et al, } \\
1995\end{array}$ \\
\hline grim & $\begin{array}{l}\text { Within } 300 \mathrm{~kb} \text { deletion that is required } \\
\text { for programmed cell death in the } \\
\text { embryo }\end{array}$ & $\begin{array}{l}\text { Novel; ablates the eye when } \\
\text { ectopically expressed }\end{array}$ & Chen et al, 1996 \\
\hline hid & $\begin{array}{l}\text { Within } 300 \mathrm{~kb} \text { deletion that is required } \\
\text { for programmed cell death in the } \\
\text { embryo; mutations in hid fail to } \\
\text { undergo embryonic head involution } \\
\text { and have supernumerary cells }\end{array}$ & $\begin{array}{l}\text { Novel; ablates the eye when } \\
\text { ectopically expressed }\end{array}$ & Grether et al, 1995 \\
\hline P35 & $\begin{array}{l}\text { Viral protein; inhibits ICE/ced-3 } \\
\text { cysteine protease activity }\end{array}$ & $\begin{array}{l}\text { Blocks normally occurring, reaper and } \\
\text { hid induced cell death in the eye }\end{array}$ & $\begin{array}{l}\text { Hay et al, 1994, 1995; Grether et al, } \\
\text { 1995; White et al, 1996; Xue and } \\
\text { Horvitz, 1995; Bump et al, } 1995\end{array}$ \\
\hline DIAP1/thread & Lethal & $\begin{array}{l}\text { Cellular homolog of baculovirus } \\
\text { inhibitor of apoptosis; blocks normally } \\
\text { occurring, reaper and hid induced cell } \\
\text { death in the eye }\end{array}$ & Hay et al, 1995 \\
\hline DIAP2 & & $\begin{array}{l}\text { Cellular homolog of baculovirus } \\
\text { inhibitor of apoptosis; blocks normally } \\
\text { occurring, reaper and hid induced cell } \\
\text { death in the eye }\end{array}$ & Hay et al, 1995 \\
\hline
\end{tabular}




\section{The progression of differentiation: Moving the furrow}

Pattern formation of the eye involves the function of a number of genes, some required for differentiation of specific cell subtypes, whereas others function to initiate, push and/or pull the morphogenetic furrow (as noted, sine oculis and eyes absent may function in furrow initiation or progression as well as other events, given that their expression initiates prior to furrow formation (Bonini et al, 1993; Cheyette et al, 1994; Serikaku and O'Tousa, 1994)). The fly homolog of transforming growth factor $\beta$ (decapentaplegic (dpp)), and hedgehog are key players in movement of the furrow. $d p p$ is expressed at the posterior margin and lateral edges of the eye progenitor field prior to furrow progression, and expression is maintained in the furrow as it moves (Heberlein et al, 1993b; Ma et al, 1993). Maintenance of $d p p$ expression within the furrow is achieved by hedgehog activity: hedgehog is expressed in the differentiating clusters posterior to the furrow, but functions to signal progenitor cells ahead of the furrow to initiate events of differentiation, including dpp expression (Heberlein et al, 1993b, 1995; Ma et al, 1993). Thus, whereas hedgehog is expressed spatially in differentiating clusters posterior to the furrow, it functions in furrow progression to induce cells ahead of the furrow into pattern formation events. Loss of hedgehog or dpp activity increases the amount of cell death ahead of the furrow, typically in a band of death just prior to the furrow (Heberlein et al, 1993b; Ma et al, 1993). One way to account for these observations is that inappropriate differentiation leads to elimination of cells by programmed death prior to furrow formation. These data support the idea of an interplay between genes functioning within progenitor cells ahead of the furrow and those involved in non-autonomous events of the dynamic patterning process being important for cell selection events of differentiation.

Initiation of furrow progression from the posterior pole of the eye disc involves the actions of additional genes, such as dachshund (Mardon et al, 1994). Loss of dachshund function at the posterior margin leads to death of some cells, and a change in fate of other cells to that of cuticle. The temporal restriction of furrow movement to a dorsalventral band progessing across the progenitor epithelial field also involves interactions that prevent precocious differentiation of the progenitor cells. This includes inhibition from the diffusible factor wingless to restrict furrow initiation to the posterior end of the disc by inhibiting progression from the lateral margins (Ma and Moses, 1995; Treisman and Rubin, 1995). The hairy and emc (extra macrochaetae) genes encode helix-loophelix proteins, and likewise prevent precocious differentiation within the progenitor field just ahead of the furrow (Brown et al, 1995). These genes are normally strongly expressed in bands several cell diameters wide anterior to the furrow, with strong emc expression preceding the band of hairy expression, and temporally regulate the rate of progression by restricting the advance of the furrow. cAMP-dependent protein kinase and patched activities are also important to regulate the rate of progression; loss of cAMP-dependent protein kinase function in clones anterior to the furrow allows precocious furrow formation, similar to ectopic hedgehog expression (Heberlein et al, 1995; Strutt et al, 1995; Pan and Rubin, 1995). Biologically, the region just anterior to the furrow is distinct from regions further anterior, since eye disc fragments that include this region can re-initiate furrow formation (Lebowitz and Ready, 1986). This region would appear to overlap the domain of strong expression anterior to the furrow of a number of the genes mentioned, including eyes absent, sine oculis, hairy, emc and string and correspond to the region where the loss of cAMPdependent protein kinase activity or ectopic hedgehog expression can initiate furrow formation de novo.

The hedgehog gene functions in furrow progression in short-range diffusible interactions, however when expressed ectopically within progenitor cells far anterior to the furrow, it stumulates division dramatically (Heberlein et al, 1995). Extension of these observations to the normal situation in vivo suggests that cellular response to hedgehog in the eye progenitor field may be concentration-dependent and differ in short-range compared to longrange interactions. Moreover, the response to hedgehog or other signals likely depends on the levels of other factors expressed in the cells which receive the signal. Some genes are only expressed just anterior to the furrow, such as hairy, whereas the expression patterns of other genes, notably eyes absent and sine oculis, are graded with weaker expression further anterior to the furrow and strong expression just anterior to the furrow. Thus, the same signal may mediate different functions based on concentration-dependence and the expression levels of other genes within the cells.

When cells enter the furrow, several genes are critical for the cellular dynamics involved in generating an array of cell clusters of the right number and spatial pattern. These genes include atonal (Jarman et al, 1995), Ellipse (Baker and Rubin, 1992), scabrous (Baker and Rubin, 1990), Notch (Cagan and Ready, 1989b), among others, and play roles in restricting the number of clusters that are initiated, as well as regulating their spacing. Other genes are important for cellular interactions that define photoreceptor and accessory cell types. In some cases, loss of function or aberrant function of these genes leads to cell death, for example, as in mutations of atonal (Jarman et al, 1995), Ellipse (Baker and Rubin, 1992) and glass (Ready et al, 1986) (whereas others, such as sevenless mutations, result in cell fate transformations to another cell of the ommatidial cluster (Tomlinson and Ready, 1986)). The timing of cell death is distinct, however, from the earlier mentioned examples where cell death is increased ahead of the furrow. In the cases described here, cells die in the posterior region of the eye disc within the developing clusters, or even later as in glass mutations with presumptive photoreceptor cells dying during the pupal stages (Ready et al, 1986). In mutations in the proneural gene atonal, which is important for selecting the founding neuron of the ommatidial clusters, cell death is dramatically increased just after the furrow (Jarman et al, 1995). Hence, in atonal mutants, normal furrow progression occurs, but no cells survive to contribute to the adult eye due to loss of the cells just after the furrow. 
During eye development, some cells are normally eliminated by cell death among the differentiated clusters, initiating about 12 rows after the furrow and continuing as a diffuse band of death (Wolff and Ready, 1991; Bonini et al, 1993; Hay et al, 1994; also Wolff and Ready, 1993). This cell death may be associated with failure of proper cell fate specification of cone and primary pigment cells, or cell cycle events. In Ellipse mutants, which represent hyperactive alleles of the Drosophila epidermal growth factor (EGF) receptor, some cells that die are presumably in the G2 phase of the cell cycle and have failed to undergo mitosis to proceed to $\mathrm{G} 1$ where they can undergo differentiation (Baker and Rubin, 1989, 1992). Altered function of additional genes required for patterning of the eye can also lead to increased cell death in the differentiating region of the disc, for example, as in Star mutations (Heberlein et al, 1993a), or flies expressing an activated form of yan, an ETS DNA binding domain protein modulated by the MAP kinase pathway (Lai and Rubin, 1992; Rebay and Rubin, 1995). The normal function of the yan gene is to inhibit progenitor cell differentiation. Expressing an activated form of yan ectopically in differentiating cells can lead to cell death (Rebay and Rubin, 1995), suggesting that if a cell receives conflicting signals of whether or not to differentiate, the net result can be to trigger programmed cell death pathways. Thus, cells may die during the differentiation process for many reasons, including failure to make appropriate contacts required to stimulate differentiation, failure to obtain sufficient levels of factors required for differentiation and/ or survival, abnormal cell cycle events, conflicting differentiation and mitotic signals, conflicting inhibitory and stimulatory signals for differentiation, among others. In sum, it may be that if a cell fails to receive an appropriate mitotic or differentiation signal by a specific time, or if it receives conflicting signals, death is the necessary outcome.

\section{Integration of cell cycle control with the differentiation process}

As noted, appropriate regulation of the cell cycle is integral to the cell differentiation process. Anterior to the furrow progenitor cells are dividing asynchronously, but just prior to pattern formation cell cycle becomes synchronized such that cells enter the furrow in the G1 phase (Ready et al, 1976; Thomas et al, 1994a). Cells recruited into clusters posterior to the furrow begin differentiation and become postmitotic, whereas the remaining progenitor cells proceed through an additional round of division (Ready et al, 1976). Cell cycle control genes and regulators, including string (homolog of the mitotic inducer cdc25 (Edgar and O'Farrell, 1989)), cyclins (Thomas et al, 1994b; Finley et al, 1996; Richardson et al, 1995), EGF signalling molecules (Baker and Rubin, 1992; Tio et al, 1994), among others to be defined (e.g. de Nooij and Hariharan, 1995), contribute to synchronization of cell cycle events with differentiation.

string is expressed in a domain anterior to the furrow that may be critical to coordinate events of cell cycle control with differentiation (Alphey et al, 1992; Thomas et al, 1994a). Within this domain, two cell cycle events are thought to occur: those cells in G1 are prevented from reentering the cell cycle, whereas those in G2 are stimulated by string function to progress through mitosis to arrest in G1 (Thomas et al, 1994b). The roughex gene encodes a novel protein whose activity is critical to synchronize the cell cycle in G1 within the furrow; with loss of roughex activity, cells fail to undergo $\mathrm{G} 1$ arrest prior to the furrow and continue division as they proceed through the furrow (Thomas et al, 1994a). roughex mutants develop eyes with fewer than the normal number of cells and display ommatidial patterning defects. In the eye disc, an increase in the numbers of cells dying within and posterior to the furrow occurs. Failure of cell cycle synchronization may lead to death of cells that receive conflicting signals of differentiation and cell division, or of cells that find themselves in the wrong phase of the cell cycle for differentiation (such as G2) but fail to receive a signal for mitosis (such as described for Ellipse mutants, above). The normal cell death that occurs ahead of the furrow overlaps the string expression domain in which cell cycle synchronization begins. One reason to eliminate a cell at this time may be its inability to undergo cell cycle synchronization events required for progression into the furrow. Thus, genes that lead to increased cell death at this time, such as eyes absent, sine oculis, dpp, and hedgehog, may influence this event as well as others.

\section{Sculpting the neurocrystalline lattice of the eye}

During pupation, two phases of cell death occur in the eye field to eliminate extraneous cells associated with the ommatidia, generating the highly ordered array characteristic of the adult compound eye. One phase occurs between 35 and $50 \mathrm{~h}$ post pupariation, and results in elimination of two or three extra secondary and tertiary pigment cells per ommatidium; these cells form the outer part of the ommatidial lattice and are shared between neighboring clusters (Cagan and Ready, 1989a; Wolff and Ready, 1991). A second burst of death occurs between 60 and $70 \mathrm{~h}$ after pupariation to eliminate perimeter ommatidia, which are frequently observed to be stunted in their position in the array (Wolff and Ready, 1991). The death of perimeter clusters occurs simultaneously across the entire epithelium, suggesting the possibility of a coordinated signalling mechanism to effect this cell loss.

Mutations in the genes roughest (also called irregular chiasm C), echinus and argos (also called giant lens and strawberry) prevent proper elimination of extraneous pigment cells during the first phase of pupal cell death, leading to adult eyes of disrupted pattern (Wolff and Ready, 1991; Brunner et al, 1994). In roughest and echinus mutants, the perimeter ommatidial deaths occur normally. The roughest gene encodes a transmembrane protein with extracellular immunoglobulin-like domains that displays homophilic adhesive interactions in vitro (Ramos et al, 1993; Schneider et al, 1995). Mutations in roughest also affect axon targeting. The roughest ${ }^{C T}$ mutation that specifically affects the eye lattice results from truncation 
of the intracellular domain of the protein and leads to altered subcellular protein localization (Schneider et al, 1995; Reiter et al, 1996). These data suggest that proper placement of the protein is critical for the selection of certain pigment cells over others for the shared lattice network. Mutants in argos also show a complete lack of cell death during the first phase of pupal cell death; the amount of cell death during differentiation of the third instar larval disc is also lower than normal (Brunner et al, 1994). The adult eye has excess cells, including photoreceptor neurons, cone cells, and pigment cells (Freeman et al, 1992; Kretzschmar et al, 1992; Okano et al, 1992; Brunner et al, 1994). The argos gene encodes a secreted protein with an EGF motif that functions over long range, and that interacts with other genes of EGF pathways (Freeman et al, 1992; Kretzschmar et al, 1992; Okano et al, 1992; Schweitzer et al, 1995). The additional cells in argos mutant eyes appear recruited from extra cells which would normally be eliminated by cell death in the larval disc and pupal eye; argos thus encodes a factor whose normal function is to inhibit neighboring cells from undergoing identical differentiation events. With more attention being paid to cell death processes, additional genes whose function is involved in survival of supernumerary cells in the eye is likely to become emphasized.

Together, these data suggest that the appropriate cell interactions and signals are important for the selection of the right number and type of cells for the ommatidial lattice. The signalling mechanisms for pigment cell selection, for example, are coupled to survival pathways. Multiple cells make the right contacts, but still only select cells survive, suggesting a competition for unknown elements (Cagan and Ready, 1989a). Genes that prevent cell death in the animal at embryonic stages and during formation of the eye, such as the baculoviral P35 protein and cellular homologs of inhibitors of apoptosis DIAP1 and DIAP2, can prevent both pigment cell and perimeter cell death in the pupal eye (Hay et al, 1994, 1995). This indicates that common molecular mechanisms of cell death pathways are activated during these cell selection processes. Moreover, cells that survive as a result of these manipulations, as well as in mutant situations where supernumerary cells differentiate - as in argos mutants - show features of normally differentiated cells. This supports the idea that supernumerary cells will undergo normal differentiation events when they are protected from elimination by cell death.

\section{Maintenance in the adult}

Selection of the appropriate cells and their correct differentiation to comprise the compound eye is only the first step toward a functioning neural structure. With the eye properly formed, the fly must then maintain it appropriately. Aberrant photoreceptor function can lead to loss of the differentiated cells. Notably, mutations in genes that affect products involved in the phototransduction cascade can lead to loss of photoreceptor cells by light-dependent or -independent manners (reviewed in Smith et al, 1991; Zuker, 1992). Such mutants include those in genes involved in phosphatidyl inositol pathways (retinal degeneration $A, B$, and $D$ ), and protein phosphatase which results in rhodopsin activation (retinal degeneration C; Steele and O'Tousa, 1992). Presumably, these mutations result in metabolic defects due to aberrant regulation of phototransduction, leading to subsequent death of the cells. Although these mutations have not yet been characterized for cell loss by programmed cell death versus degeneration by necrosis, vertebrate mutations in rhodopsin in forms of retinitis pigmentosa lead to death by apoptosis (Portera-Cailliau et al, 1994; Chang et al, 1994; see accompanying reviews). Thus, it is likely that cell loss occurs in at least some of these mutations through activation of programmed cell death pathways.

Trophic interactions between the eye and the brain are critical to long-term survival of the neural structure. Eyes that develop ectopically due to select mutations (for example, extra eye) or that develop in the absence of proper synaptic connections with the brain (disconnected mutants), develop relatively normal compound eye structures (Marcey and Stark, 1985; Steller et al, 1987). However, in such cases, since the axons of the photoreceptor neurons fail to connect with the optic centers of the brain, the photoreceptor cells fail to be maintained in the adult (Campos et al, 1992). Again, whether this cell loss is through programmed cell death pathways or degeneration by necrosis remains to be defined. Nevertheless, these studies indicate trophic interactions between the eye and brain, similar to such interactions fundamental to vertebrate cell selection (Cowan et al, 1984; Oppenheim, 1991; Raff et al, 1993), are critical to long-term neural maintenance in the fly.

\section{The eye as a probe to dissect molecular components of cell death pathways}

Genes involved in triggering cell death or effecting cell survival have been identified in Drosophila. One chromosomal region critical for all normally occurring cell death in the embryo is defined by an approximately $300 \mathrm{~kb}$ deletion that includes at least three genes, reaper, head involution defective (hid) and grim, known to be important to effect cell death in the animal (White et al, 1994; Grether et al, 1995; Chen et al, 1996). The Drosophila eye provides a powerful selection assay to reveal additional genes that function upstream or downstream of cell death genes, or otherwise modify the activity of these genes to kill cells. Ectopic expression in eye cells of genes that prevent cell death disrupts the highly regular lattice of the compound eye (Hay et al, 1994). Moreover, similar expression of genes that effect killing can ablate the eye (Grether et al, 1995; Hay et al, 1995; Chen et al, 1996; White et al, 1996); these effects are dominant and sensitive to gene dosage. Hence, regions of the genome that contain new genes that may modify the function of cell death genes can be detected by altering gene dosage with the large number of available Drosophila chromosomal deletions, among other techniques. In this way, cellular homologs of baculoviral inhibitor of apoptosis genes have already been defined by the ability to enhance ablation of the eye by ectopic hid or reaper when present in one versus two copies (Hay et al, 1995). The eye can thus be used as a 
window into cell death pathways of the fly, to define molecular components of cell death regulation in the organism. Once such genes are identified, their normal function in the organism in development, cell survival and maintenance are of issue.

\section{Conclusions/future focus}

Cell death is integral to normal differentiation of the fly eye. It occurs at multiple points in the developmental process, and is essential for the appropriate differentiation of the structure (see Figure 1). A common theme that characterizes the results of a number of mutations in genes essential for proper eye differentiation and/or patterning is to lead to death of cells (see Table 1). Cell death may be the default fate of eye cells should they develop at inappropriate times or receive inappropriate amounts of factors or signals required for differentiation, receive conflicting signals such as for division and differentiation, or fail to make appropriate contacts with target cells for survival. Thus, the activities of genes involved in eye patterning are integrated into survival pathways. Moreover, hormonal interactions are of critical importance to the differentiation of many adult structures, including the eye. Hormones such as ecdysone influence the survival of specific cells within the nervous system through regulation of programmed cell death pathways (Truman et al, 1992). Thus, hormonal signals, local diffusible molecules, as well as cell autonomous factors all dynamically integrate to make the exquisitely organized structure of the fly compound eye. How this is achieved in molecular detail is a key to understand cell selection during the differentiation process. Are signals for survival the same as those for specific aspects of cell differentiation? How the signalling processes of survival interplay with differentiation genes will be a key focus for the future. The Drosophila eye provides an experimental system in which to dissect the interwoven pathways of cell differentiation and cell death to define how groups of cells are sculpted to generate a functioning neural structure.

\section{Acknowledgements}

Thanks to A. Cashmore, L. Lillien, K. Zinsmaier, and members of the Bonini laboratory for comments. N.B. is supported by grants from the John Merck Fund, March of Dimes, NIH, and University of Pennsylvania Research Foundation.

\section{References}

Abrams JM, White K, Fessler LI and Steller H (1993) Programmed cell death during Drosophila. embryogenesis. Development 117: 29-43

Alphey L, Jiminez J, White-Cooper H, Dawson I, Nurse P and Glover D (1992) twine, a cdc25 homolog that functions in the male and female germline of Drosophila. Cell 69: $977-988$

Baker NE, Mlodzik M and Rubin GM (1990) Spacing differentiation in the developing Drosophila eye: a fibrinogen-related lateral inhibitor encoded by scabrous. Science 250: $1370-1377$

Baker NE and Rubin GM (1989) Effect on eye development of dominant mutations in Drosophila homologue of the EGF receptor. Nature 340: 150-153

Baker NE and Rubin GM (1992) Ellipse mutations in the Drosophila homologue of the EGF receptor affect pattern formation, cell division, and cell death in eye imaginal discs. Developmental Biol. 150: 381-396
Banfi S, Borsani G, Rossi E, Bernard L, Guffanti A, Rubboli F, Marchitiello A, Giglio S, Coluccia E, Zollo M, Zuffardi O and Ballabio A (1996) Identification and mapping of human cDNAs homologous to Drosophila mutant genes through EST database searching. Nature Genetics 13: 167-174

Bonini NM and Choi K-W (1995) Early decisions in Drosophila eye morphogenesis. Curr. Op. Gene. Devel. 5: 507-515

Bonini NM, Leiserson WM and Benzer S (1993) The eyes absent gene: Genetic control of cell survival and differentiation in the developing Drosophila eye. Cell 72: $379-395$

Brown N, Sattler C, Paddock S and Carroll S (1995) Hairy and Emc negatively regulate morphogenetic furrow progression in the Drosophila eye. Cell 80: 879887

Brunner A, Twardzik T and Schneuwly S (1994) The Drosophila giant lens gene plays a dual role in eye and optic lobe development: Inhibition of differentiation of ommatidial cells and interference in photoreceptor axon guidance. Mech. Development 48: 175-185

Bryant P (1988) Localized cell death caused by mutations in a Drosophila gene coding for a transforming growth factor-beta homolog. Dev. Biol. 128: 386-395

Bump N, Hackett M, Hugunin M, Seshagiri S, Brady K, Chen P, Ferenz C, Franklin S Ghayur T, Li P, Licari P, Mankovich J, Shi L, Greenberg A, Miller L and Wong W (1995) Inhibition of ICE family proteases by baculovirus antiapoptotic protein p35. Science 269: 1885-1888

Cagan RL and Ready DF (1989a) The emergence of order in the Drosophila pupal retina. Dev. Biol. 136: 346-362

Cagan RL and Ready DF (1989b) Notch is required for successive cell decisions in the developing Drosophila retina. Genes Dev. 3: 1099-1112

Campos AR, Fishbach K-F and Steller H (1992) Survival of photoreceptor neurons in the compound eye of Drosophila depends on connections with the optic ganglia. Development 114: 355-366

Chang GQ, Hao $Y$ and Wong $F$ (1993) Apoptosis: final common pathway of photoreceptor death in rd, rds, and rhodopsin mutant mice. Neuron 11:595-605

Chen P, Nordstrom W, Gish B and Abrams J (1996) grim, a novel cell death gene in Drosophila. Genes Dev. 10: 1773-1782

Cheyette BNR, Green PJ, Martin K, Garren H, Hartenstein V and Zipursky SL (1994) The Drosophila sine oculis locus encodes a homeodomain-containing protein required for the development of the entire visual system. Neuron 12: 977-996

Cowan WM, FawcettJW, O'Leary DDM and Stanfield BB (1984)Regressive events in neurogenesis. Science 225: 1258-1265

de Nooij JC and Hariharan IK (1995) Uncoupling cell fate determination from patterned cell division in the Drosophila eye. Science 270: 983-985

Edgar BA and O'Farrell PH (1989) Genetic control of cell division patterns in the Drosophila embryo. Cell 57: 177-187

Finley RL, Thomas BJ, Zipursky SL and Brent R (1996) Isolation of Drosphila cyclin D, a protein expressed in the morphogenetic furrow before entry into $S$ phase. Proc. Natl. Acad. Sci. USA 93: 3011-3015

Freeman M, Kimmel BE, Goodman C and Rubin GM (1992) The argos gene encodes a diffusible factor that regulates cell fate decisions in the Drosophila eye. Cell 69 : $963-975$

Fristrom D (1969) Cellular degeneration in the production of some mutant phenotypes in Drosophila melanogaster. Mol. Gen. Genetics 103: 363-379

Grether ME, Abrams JM, Agapite J, White K and Steller H (1995) The head involution defective gene of Drosophila melanogaster functions in programmed cell death. Genes Devel. 9: 1694-1708

Halder G, Callaerts P and Gehring W (1995) Induction of ectopic eyes by targeted expression of the eyeless gene of Drosophila. Science 267: 1788-1792

Hay BA, Wassarman DA and Rubin GM (1995) Drosophila homologs of baculovirus inhibitor of apoptosis proteins function to block cell death Cell 83: 1253-1262

Hay BA, Wolff T and Rubin GM (1994) Expression of baculovirus P35 prevents cell death in Drosophila. Development 120: 2121-2129

Heberlein U, Hariharan IK and Rubin GM (1993a) Star is required for neurona differentiation in the Drosophila retina and displays dosage-sensitive interactions with Ras1. Dev. Biol. 160: 51-63

Heberlein U and Moses K (1995) Mechanisms of Drosophila retinal morphogenesis: The virtues of being progressive. Cell 81: $987-990$

Heberlein U, Singh CM, LukAY and DonohoeTJ(1995) Growth and differenatiation in the Drosophila eye coordinated by hedgehog. Nature 373: 709-711

Heberlein U, Wolff T and Rubin GM (1993b) The TGF $\beta$ homolog dppand the segment polarity gene hedgehogare required for propagation of a morphogenetic wave in the Drosophila retina. Cell 75: 913-926 
Jarman AP, Grell EH, Ackerman L, Jan LY and Jan YN (1994) atonal is the proneural gene for Drosophila photoreceptors. Nature 369: 398-400

Jarman AP, Sun Y, Jan LY and Jan YN (1995) Role of the proneural gene, atonal, in formation of Drosophila chordotonal organs and photoreceptors. Development 121: $2019-2030$

Kerr JFR, Wyllie AH and Currie AR (1972) Apoptosis: a basic biological phenomenon with wide ranging implications in tissue kinetics. Br. J. Cancer 26: 239-257

Kretzschmar D, Brunner A, Wiersdorff V, Pflugfelder GO, Heisenberg M and Schneuwly $S$ (1992) giant lens, a gene involved in cell determination and axonal guidance in the visual system of Drosophila melanogaster. EMBO J. 11:2531 2539

Kunes S, Wilson C and Steller H (1993) Independent guidance of retinal axons in the developing visual system of Drosophila. J. Neurosci. 13: 752-767

Lai Z-C and Rubin GM (1992) Negative control of photoreceptor development in Drosophila by the product of the yangene, an ETS domain protein. Cell 70:609620

Lebovitz RM and Ready DF (1986) Ommatidial development in Drosophila eye disc fragments. Dev. Biol. 117: 663-671

Ma C and Moses K (1995) wingless and patched are negative regulators of the morphogenetic furrow and can affect tissue polarity in the developing Drosophila compound eye. Development 121: 2279-2289

Ma C, Zhou Y, Beachy PA and Moses K (1993) The segment polarity gene hedgehog is required for progression of the morphogenetic furrow in the developing Drosophila eye. Cell 75: $927-938$

Marcey DJ and Stark WS (1985) The morphology, physiology, and neuronal projections of supernumerary compound eyes in Drosophila melanogaster. Dev. Biol. 73: 180-197

Mardon G, Solomon NM and Rubin GM (1994) dachsund encodes a nuclear protein required for normal eye and leg development in Drosophila. Development 120: $3473-3486$

Okano H, Hayashi S, Tanimura T, Sawamoto K, Yoshikawa S, Watanabe J, Iwasaki M, Hirose S, Mikoshiba K and Montell C (1992) Regulation of Drosophila neural development by a putative secreted protein. Differentiation 52: 1-11

Oppenheim RW (1991) Cell death during development of the nervous system. Annu. Rev. Neurosci. 14: 453-501

Pan D and Rubin GM (1995) cAMP-dependent protein kinase and hedgehog act antagonistically in regulating decapentaplegic transcription in Drosophila imaginal discs. Cell 80: 543-552.

Portera-Cailliau C, Sung CH, Nathans J and Adler R (1994) Apoptotic photoreceptor cell death in mouse models of retinitis pigmentosa. Proc. Natl. Acad. Sci. USA 91: 974-978

Quiring R, Walldorf U, Kloter U and Gehring WJ (1994) Homology of the eyeless gene of Drosophila to the small eye gene in mice and aniridia in humans. Science 265 : $785-789$

Raff MC, Barres BA, Burne JF, Coles HS, Ishizaki Y and Jacobsen MD (1993) Programmed cell death and the control of cell survival: lessons from the nervous system. Science 262: $695-700$

Ramos RGP, Igloi GL, Lichte B, Baumann U, Maier D, Schneider T, Brandstatter JH, Frohlich A and Fischbach K-F (1993) The irregular chiasm C-roughest locus of Drosophila, which affects axonal projections and programmed cell death encodes a novel immunoglobulin-like protein. Genes Dev. 7: 2533-2547

Ready DF, Hanson TE and Benzer S (1976) Development of the Drosophila retina, a neurocrystalline lattice. Dev. Biol. 53: 217-240

Ready DF, Tomlinson A and Lebovitz RM (1986) Building an ommatidium: Geometry and genes. In Development of Order in the Visual System, Hilfer SR and Sheffield JB, eds. (New York: Springer Verlag) pp. 97-125

Rebay I and Rubin GM (1995) Yan functions as a general inhibitor of differentiation and is negatively regulated by activation of the Ras1/MAPK pathway. Cell 81 $857-866$

Reiter C, Schimansky T, Nie Z and Fischbach K-F (1996) Reorganization of membrane contacts prior to apoptosis in the Drosophila retina: the role of the IrreC-rst protein. Development 122: 1931-1940
Richardson H, O'Keefe LVO, Marty T and Saint R (1995) Ectopic cyclin E expression induces premature entry into $S$ phase and disrupts pattern formation in the Drosophila eye imaginal disc. Development 121: 3371 - 3379

Schneider T, Reiter C, Eule E, Bader B, Lichte B, Nie Z, Schimansky T, Ramos RGP and Fischbach K-F (1995) Restricted expression of the irreC-rst protein is required for normal axon projections of columnar visual neurons. Neuron 15 259-271

Schweitzer R, Howes R, Smith R, Shilo B-Z and Freeman M (1995) Inhibition of Drosophila EGF receptor activation by the secreted protein Argos. Nature 376 $699-702$

Serikaku MA and O'Tousa JE (1994) sine oculis is a homeobox gene required for Drosophila visual system development. Genetics 138: 1137-1150

Smith DP, Stamnes MA and Zuker CS (1991) Signal transduction in the visual system of Drosophila. Annu. Rev. Cell Biol. 7: 161-190

Spreij TE (1971) Cell death during the development of the imaginal disks of Calliphora erythrocephala. Neth. J. Zool. 21: 221-264

Steele F and O'Tousa JE (1990) Rhodopsin activation causes retinal degeneration in Drosophila rdg $C$ mutant. Neuron 4: 883-890

Steller H, Fischbach K-F and Rubin GM (1987) disconnected: A locus required for neuronal pathway formation in the visual system of Drosophila. Cell 50: 11391153

Strutt DI, Wiersdorff V and Mlodzik M (1995) Regulation of furrow progression in the Drosophila eye by cAMP-dependent protein kinase A. Nature 373: 705-709

Thomas BJ, Gunning DA, Cho J and Zipursky SL (1994a) Cell cycle progression in the developing Drosophila eye: roughex encodes a novel protein required for the establishment of G1. Cell 77: 1003-1014

Thomas BJ and Zipursky SL (1994b) Early pattern formation in the developing Drosophila eye. Trends Cell. Biol. 4: 389-394

Tio M, Chaoyong M and Moses K (1994) spitz, a Drosophila homolog of transforming growth factor-alpha, is required in the founding photoreceptor cells of the compound eye facets. Mech. Dev. 48: 12-23

Tomlinson A and Ready DF (1986) Sevenless: A cell-specific homeotic mutation of the Drosophilia eye. Science 231: 400-402

Treisman JE and Rubin GM (1995) wingless inhibits morphogenetic furrow movement in the Drosophila eye disc. Development 121: 3519-3527

Truman JW, Thorn RS and Robinow S (1992) Programmed neuronal death in insect development. J Neurobiol. 23: 1295-1311

White K, Grether ME, Abrams JM, Young L, Farrell K and Steller H (1994) Genetic control of programmed cell death in Drosophila. Science 264: 677-683

White Kand Steller H(1995) The control of apoptosis in Drosophila. Trends Cell. Biol. 5: $74-78$

White K, Tahaoglu E and Steller H (1996) Cell killing by the Drosophila gene reaper Science 271: 805-807

Wolff T and Ready DF (1991) Cell death in normal and rough eye mutants of Drosophila. Development 113: 825-839

Wolff T and Ready DF (1993) Pattern formation in the Drosophila retina. In the Development of Drosophila melanogaster, Bate M, Martinez-Arias A, eds. (Cold Spring Harbor: Cold Spring Harbor Laboratory Press) pp. 1277-1325

Xue D and Horvitz $\mathrm{H}$ (1995) Inhibition of the Caenorhabditis elegans cell-death protease CED-3 by a CED-3 cleavage site in baculovirus p35 protein. Nature 377: $248-251$

Zipursky SL and Rubin GM (1994) Determination of neuronal cell fate: lessons from the R7 neuron of Drosophila. Annu. Rev. Neurosci. 17: 373-397

Zuker C (1992) Phototransduction in Drosophila: a paradigm for the genetic dissection of sensory transduction cascades. Curr. Op. Neurobiol. 2: 622-627

Zuker CS (1994) On the evolution of eyes: would you like it simple or compound. Science 265: $742-743$ 